\title{
Kriz Zamanlarında Sosyal Mesafe
}

\author{
Kadir Canatan* \\ İstanbul Sabahattin Zaim Üniversitesi
}

\begin{abstract}
Öz
Bu makale, doğal ve sosyal felaketlerin ya da başka bir deyişle krizlerin sosyal mesafe üzerindeki etkileri konusunda sosyolojik bir tartışma yapmayı amaçlamaktadır. Tartışmanın çıkış noktasını, kriz dönemlerinde normal hayat seyrinin ve bunu düzenleyen normların geçersiz ve kullanışsız olduğu fikri oluşturmaktadır. Kriz, günlük ezber ve rutinlerin bozulmasını beraberinde getirir. Normal zamanlarda geçerli olan sosyal mesafe ölçüleri kriz dönemlerinde anlamlı olmaktan çıkar ve hatta sakıncalı bir hale gelir. Bu nedenle insanlık sadece normal dönemlerde geçerli olan normları değil, kriz dönemlerinde de geçerli olabilecek normları üretmiş ve gerektiğinde bunları uygulamıştır. Krizin etkileri, niteliğine bağlı olarak değiştiği gibi, kısa ve uzun süreli olmasına bağlı olarak da farklılaşmaktadır.
\end{abstract}

\section{Anahtar Kelimeler}

sosyal mesafe, krizler, korona salgını ve sosyal ilişkiler

\section{Social Distance in Crisis Times}

\begin{abstract}
This article aims to have a sociological discussion about the effects of natural and social disasters, or crises on social distance. The starting point of the discussion is the idea that the normal life course and the norms that regulate it during periods of crisis are invalid and unusable. The crisis brings with it the disruption of daily routines. Social distance measures, which are valid in normal times, do not make sense during crisis periods and even become objectionable. For this reason, humanity has produced not only the norms that are valid in normal periods, but also the norms that can be valid in times of crisis, and activates them when necessary. The effects of the crisis differ depending on the nature of the crisis, as well as being short and long term.
\end{abstract}

\section{Keywords}

social distance, crises, corona epidemic and social relations

* Prof. Dr., İstanbul Sabahattin Zaim Üniversitesi, Sağlık Bilimleri Fakültesi, Sosyal Hizmet 


\section{Extended Abstract}

\section{Introduction}

This article aims to have a sociological discussion about the effects of natural and social disasters, or crises on social distance. The starting point of the discussion is the idea that the normal life course and the norms that regulate it during periods of crisis are invalid and unusable. The crisis brings with it the disruption of daily routines. Social distance measures, which are valid in normal times, do not make sense during crisis periods and even become objectionable. For this reason, humanity has produced not only the norms that are valid in normal periods, but also the norms that can be valid in times of crisis, and activates them when necessary. The effects of the crisis differ depending on the nature of the crisis, as well as being short and long term.

The concept of social distance is related to spatial closeness and distance in social relations. Describes the degree of proximity and distance between individuals and social groups. An American sociologist who develops a social distance scale defines the concept as "the degree of acceptance and closeness we feel towards others". When we think with the general concepts of sociology, the family and familiar environment that realizes primary socialization is an environment where social distance is least experienced. In contrast, units such as social environment, street, friendship and school, which carry out secondary socialization, are environments where social distance gradually increases and accordingly the degree of acceptance decreases. Cultural anthropology emphasizes the importance of ingroup-outgroup separation in pre-modern societies. Especially in tribal societies, a person is a member of his own tribe and tribe and is in solidarity with members of this social group to which he is a member. The social distance is so low that the members are almost identified with each other. An attack on one is perceived as an attack on all tribal members. The consequence of this is that crime and punishment have a collective character in such societies. Members of a tribe see groups and tribes other than their own strangers, rivals and even enemies.

Different dimensions of social distance can be distinguished. If we consider the intensity of social relations between groups, we are talking about the social dimension of distance. If we are measuring emotional commitment or belonging to the community or group, then the emotional dimension appears. We can add a cultural dimension to these two dimensions. The cultural distance comes to the fore when it comes to the degree of cultural adaptation to the group or society. Of course, we can think that there is a relationship between them. The social dimension can be seen as a basis for developing the emotional and cultural dimension. The individual, who has frequent relationships with a group, will increasingly identify with the group emotionally and culturally. 


\section{Minimum and Maximum of Social Distance}

In everyday encounters as well as meeting or being introduced, some cultures do not allow close contact, and in some societies, limited physical contact is considered normal. In Jopanya, for example, while it is sufficient to lean slightly, it is seen as a sufficient greeting, while in many societies, oral greeting is accompanied by a handshake. Handshaking is a point where social distance is zeroed. Because the two people shake each other's hands and establish a physical contact. In fact, people who are more sincere in doing this even exhibit behaviors such as hugging and kissing. This can be defined as a sign of forward sincerity and trust.

Handshake is very common in European, American and Middle Eastern countries and its history goes back to very old times. In Muslim culture, behaviors such as greetings and complementary handshaking and even hugging are carried out to strengthen friendship, peace and solidarity among people. With these actions, people send messages to each other as "I am your friend" or "I will not harm you."

To give a few examples from the Western world, in the Netherlands and Belgium, especially in meetings, handshakes are more frequent. In Switzerland, women are expected to shake hands first. Austrians often shake hands with the children at meetings. In the United States, a traditional handshake is performed with the right hand, with good posture and eye contact. In Norway, where a solid handshake is preferred, people often shake hands in deals, private and business dealings.

The zero point of social distance is shaking, the extreme point is social isolation. There are two known forms of social isolation: ghettoization and quarantine. The word ghetto is an Italian word, a word describing the concentration and residence of a group in a particular location. It is derived from the word geta in the language of the Venetians and refers to the remains from the iron foundry. The reason for this is that there is an iron foundry in Italy where Jews have to live.

The aim of ghettoization is to set a distance between the groups that are objectionable and threatening and the settled society. It can be said that this distance has a dual function: On the one hand, the society is protected from the group perceived as a threat, and on the other hand, it is prevented that the group feels as a group belonging to the society. Due to the social distance, prejudices and stereotypes occur about the group in question, sometimes settling in society for centuries and becoming impossible to dispose of.

Quarantine is a medical term to the opposite of the ghetto, and emerged in Italy during the plague epidemic in the 14th century. During the plague epidemic, ships arriving at the ports were kept for 40 days and crew and passengers were prohibited from leaving the ship during this time. The word quarantine 
is derived from the word "quaranta", which corresponds to the number 40 in Italian. Quarantine is a precautionary activity taken by not bringing people and animals in doubt to an infectious disease into contact with anyone for an equal period of the disease's longest incubation period, it is a health isolation.

There is a fundamental difference between the ghetto and quarantine: the first tends to exclude people, while the second tends to protect people. But it can also be said that they meet on a common denominator: Persons with insulation in both are declared as "objectionable". This drawback is fictional in the first and realistic in the second.

\section{Effects of Crises on Social Distance}

Since crises cause daily routines to deteriorate, we have to rethink everything. The criteria we use on normal days change, we may even need to review our very rooted habits. Since the first weeks of the corona virus outbreak and spread to the world, the memorization of our lives has been ruined. The most important change occurred in daily life traffic. In addition, corona virus outbreak, economy, education, politics, health, media; In short, it deeply affects all areas and dimensions of our lives.

So, how do crises affect social distance, especially the corona virus outbreak that we live in?

If we try to draw conclusions from the crisis we are experiencing today, this will be deceptive. When we examine different types of crises, it seems possible to develop an ideal-typical triple typology:

1) Natural disasters such as earthquakes: While increasing social solidarity, social distance decreases.

2) Infectious diseases: It increases both social solidarity and social distance.

3) Violent acts such as terrorism: Increases hostility (hence social distance) to activists, but increases solidarity with victims (hence decreases social distance).

For social scientists, "social solidarity" and "social integration" are concepts that express the soundness of the social structure. Especially in modern society, excessive individualization, decreased social control, increased anomy, etc. developments solve the social structure and social solidarity networks. Modern society is "to become abstract", as the sociologist Zijderveld put it. According to him, modern society is an "abstract society". In abstract society, the network of relationships is diversifying, becoming fragile, and has a very flexible and distant shape. While these happen in a structural sense, cultural values become general, uncertain and free floating-traveling (Zijderveld, 2014). 
While these developments occur in modern society and everyone tries to justify these developments, sudden crises have unexpected effects and consequences in our lives. Most disasters often increase social solidarity. People interlock each other to combat the crisis and try to heal the wounds with the synergy created by this interlocking.

\section{Conclusion}

It is possible to summarize the results we have reached in a few points in this article where the effects of crises on social distance are discussed. First of all, crises activate a process in which rules and standards regarding social distance that are valid in normal days are broken and reconsidered. This process is a difficult process to endure and cope with. Because human beings cannot leave their habits easily.

Secondly, the impact of crises on social distance should not be considered as a one-way and uniform effect. Some crises increase social distance and solidarity at the same time as seen in the example of earthquakes, while others decrease social distance and increase social solidarity. Especially the coronavirus outbreak that is being experienced today should be evaluated in this second category. In other crises, as seen in terrorist incidents, while social distance is considered exclusively for activists, it is exclusionary at the extreme point, while there is no social distance against victims and solidarity is quite high.

Finally, the period of crises should be seen as a timeframe where incidental evaluation and social norms are temporarily canceled. The law specific to these periods, as stated in Mecelle, is the law that states "Obligations frees what is prohibited". All the precautions taken, from the cancellation of worshiping in shrines to the application of daily life rituals such as handshaking and hugging, are to cope with and avoid the crises. These are legitimate and functional measures as long as they are aimed at this purpose. 


\section{Giriş}

Sosyal ve doğal yaşamda belirli düzenliliklerin olması, bilim insanlarına bilim yapma imkânını bahşeden ontolojik bir zemindir. Bu noktada bilim ve din ortak bir görüșe sahiptir: Her ikisi de evrende bir düzenin varlığını kabul eder. Bununla birlikte bu düzenliliği anlamlandırma ve kullanma açısından aralarında farklar vardır. Bilim, bizatihi bu düzenlilikleri keşfetme ve formülasyonlara bağlamak isterken, din bu düzenliliği akıllı ve yaratıcı bir gücün ifade biçimi olarak görür. Teolojide "düzen” delili, Tanrı'yı kanıtlamak için kullanılan önemli bir kanıttır. Hikmetten yoksun bugünkü modern bilimin gerçeklik ötesine taşan aşkın bir boyutu yoktur. Deyim yerindeyse modern bilimde geçerli olan şey, "Bilim, bilim için yapılır” kuralı ya da "Bilgi güçtür" anlayışıdır. Bilimde düzenlilikler, gerçekliği olduğu gibi anlamak, açlklamak ve biraz da geleceği öngörmek içindir.

Düzenlilikler kadar düzenliliklerin kesintiye uğraması da din ve bilim açısından farklı yorumlanır ve anlamlandırılır. Eski Yunan felsefesinde düzen "kosmos", düzensizlik ise "kaos" olarak adlandırılmıştır. Eski Yunanlıların gözünde kosmos, aynı zamanda evrendir, çünkü evren dakik bir düzene sahip olarak algılanır. Kosmosun kaosa dönüştüğü anlar, kriz anlarıdır. Kelimenin Latince kökeni, krizin ne anlama geldiği konusunda bize bir nebze olsun yardımcı olur. Kriz kelimesi, etimolojik olarak "kırılma noktası" anlamına gelmektedir. Düzenli işleyen bir süreç kesintiye uğradığı zaman kriz meydana gelir. Bu kelime, daha sonra günlük hayat, ekonomi ve psikolojide çeşitli biçimlerde kullanılmaya başlamıştır, ama nerede ve hangi alanda kullanılırsa kullanılsın kırılgan ve kritik bir duruma işaret eder. Günlük hayatta sistemin işleyişini bozan acil durumlara kriz denir. Psikoloji ve tıpta, bir hastalığın kritik aşaması kriz olarak adlandırılır. Ekonomide ise, genellikle durağanlık ve gerileme bir kriz olarak algılanır.

Bilim açısından kriz, istenmeyen ve hemen düzeltilmesi gereken bir durumdur. Sözgelimi modern tıbbın gözünde bir otomobilin bozulması ile bir insanın hastalanması arasında bir fark yoktur. İlkini tamir ettirmek için tamirhaneye, ikincisini iyileştirmek için hastaneye gitmek gerekir. Belli ki teknik ve biyolojik sistemde bir arıza, krize yol açmıştır. Arıza düzeltildikten sonra kriz atlatılmış olur. Bilimin zıddına din (daha doğrusu dini otoriteler) krizleri daha farklı yorumlar. Sözgelimi mikro düzeyde bir hastalık ya da makro düzeyde bir felaket (doğal veya sosyal olması pek bir şey değiştirmez) kişinin veya toplumun yaptığı bir eyleme karşılık olarak görülür. Bunun savuşturul- 
ması için kişi ve toplumun kendi eylemlerini düzeltmesi ve ıslah etmesi, ayrıca Tanrı'dan yardım dilemesi beklenir.

İster sosyal felaketler isterse doğal felaketler biçiminde karşımıza çıksın, krizlerin sebepleri kadar sonuçları da önemli bir tartışma konusudur. Sosyal bilimciler krizlerin sosyal yapı ve ilişkilere etkilerini ele alırlar ve bunun mevcut yapı ve ilişkileri nasıl değiştireceğini hesap ederler. Oldukça geniş bir alanı kapsayan bu konunun, biz sadece "sosyal mesafe" yönüyle, yani krizlerin sosyal mesafeye etkileriyle ilgileniyoruz. Bu yazımızda özellikle bu noktaya yoğunlaşmak istiyoruz.

\section{Sosyal İlişkilerin Uzamsal Çerçevesi: Sosyal Mesafe}

Günlük hayat içinde kurduğumuz ilişkilerde, her zaman farkında olmasak da bu ilişkilerin çerçevesini oluşturan mekân, mesafe, süre ve ifade biçimleri çok önemli bir yer tutar. İki insan sokakta karşılaştığında belirli bir uzaklıktan birbirlerine bakarak geçip giderler. Sadece uzun süreli bir bakış ya da kızgın bir bakış, bu karşılaşmayı problematik bir hale getirebilir. Bakışmanın süresi kadar bakışın biçimi de "uygar" normlara uygun olmalıdır. Bu normlar aşıldığında kişi kendini tehdit altında hisseder. Yeni bir kişiyle tanışacaksanız, bu tanışmanın şekli ve tokalaşmanın olup olmayacağına, olacaksa nasıl olacağına toplumsal normlar karar verir. Müslüman bir toplumda iseniz, tanıştığınız kişinin cinsiyeti önemlidir. Çünkü bu husus, tokalaşmanın olup olmayacağını belirleyici bir etkendir. Ama bu bir açıdan çok önemli de olmayabilir. Hangi Müslüman ülkede ve hangi toplum kesimiyle muhatap olduğunuz da önemlidir. Demek ki, ilişkileri belirleyen kodları bilmek yeterli değildir, bunları ne zaman nerede ve nasıl kullanacağınızı da bilmeniz gerekir.

Sosyal mesafe kavramı, sosyal ilişkilerde uzamsal yakınlık ve uzaklıkla ilgilidir. Birey ve sosyal grupların birbirleri karşısında koyduğu yakınlık ve uzaklık derecesini anlatır. Sosyal mesafe ölçeği geliştiren Amerikalı bir sosyolog kavramı, "başkaları karşısında hissettiğimiz kabul ve yakınlık derecesi" olarak tanımlamaktadır (Bogardus, 1933). Sosyolojinin genel kavramlarıyla düşündüğümüzde, birincil sosyalleşmeyi gerçekleştiren aile ve tanıdık çevre sosyal mesafenin en az deneyimlendiği bir ortamdır. Buna zit olarak ikincil sosyalleştirmeyi gerçekleștiren sosyal çevre, sokak, arkadaşlık ve okul gibi birimler ise sosyal mesafenin giderek arttığı ve buna bağlı olarak kabul derecesinin de düştüğü ortamlardır. Kültürel antropoloji, pre-modern toplumlarda iç grupdış grup (ingroup-outgroup) ayrımının önemini vurgular. Özellikle kabile toplumlarında bir insan kendi kabile ve aşiretinin üyesidir ve üyesi olduğu bu sosyal grubun üyeleriyle dayanışma içindedir. Sosyal mesafe öylesine düşüktür ki, üyeler neredeyse birbirleriyle özdeşleşmişlerdir. Birine yapılan saldırı, tüm kabile üyelerine yapılmış bir saldırı olarak algılanır. Bunun beraberinde getirdiği sonuç, bu tip toplumlarda suç ve cezanın kollektif bir karakter taşı- 
masıdır. Bir kabilenin üyeleri, kendi dışındaki gruplar ve kabileleri yabancı, rakip ve hatta düşman görürler.

Sosyal mesafenin farklı boyutları ayırt edilebilir. Gruplar arasında sosyal ilişkilerin yoğunluğunu dikkate alırsak, mesafenin sosyal boyutunu konuşuyoruz demektir. Toplum veya grupla duygusal bağlılığını ya da aidiyetini ölçüyorsak, o zaman duygusal boyut karşımıza çıkar. Bu iki boyuta bir de kültürel boyutu ekleyebiliriz. Gruba ya da topluma kültürel uyum derecesi söz konusu olduğunda kültürel mesafe gündeme gelir. Elbette bunlar arasında da bir ilişki olduğunu düşünebiliriz. Sosyal boyut, duygusal ve kültürel boyutu geliştiren bir zemin olarak görülebilir. Bir grupla sıkça ilişki içinde olan birey, giderek o grupla duygusal ve kültürel anlamda da özdeşleşecektir.

Günümüzde sosyal mesafe araștırmaları, genellikle dezavantajlı gruplarla bağlantılı olarak yapılmaktadır. Bu grupların toplum tarafindan ne kadar dışlandıkları ya da tersinden bu grupların kendilerini toplumdan ne kadar yalıtladıkları önemli bir araştırma konusudur. Avrupa'da göçmen kökenli azınlıklar, genellikle topluma entegre olamayan ve kendini yalıtlayan gruplar olarak algılanmaktadır. Hollanda'da farklı etnik gruplar üzerine yapılan bir araştırmada, iki model olduğu görülmüştür. Türk ve Faslı göçmenlerin içinde yer aldığı bir modelde kişiler genellikle kendi grubundan insanlarla ilişki kurmakta ve Hollandalılarla mesafeli bir ilişki içinde olmaktadırlar. Buna karşın Sürinam ve Antillerin içinde yer aldığı diğer bir modelde ise, göçmenler karma bir arkadaş grubuyla ilişkiler kurmaktadır. Bunların Hollandalılarla aralarında daha az sosyal mesafe koydukları saptanmıştır (Huijnk \& Dagevos, 2012).

Türkiye'de kırsal kesimde halkın depresyonlu hastalara ilişkin tutumları, sosyal mesafe ve bunları etkileyen etmenler araştırma konusu yapılmıştır (Taşkın vd., 2006). Araştırmaya göre kırsal kesimde depresyonu tanıma ve depresyon konusundaki bilgi düzeyi kentsel kesime benzer şekilde ve yeterli orandadır. Ancak depresyonlu hastaları damgalama eğilimi kırsal kesimde kentsel alanda yaşayanlardan daha fazladır. Depresyonu olan bireylere karşı kırsal kesimde yaşayan halkın tutumları genel olarak daha olumsuz ve reddedicidir.

Sosyal mesafe konusunda dünyada yapılan en kapsamlı araştırma Dünya Değerler Araştırması'dır (World Values Survey, 2020). Bu araştırmada insanlara hangi grupları komşu olarak kabul edip etmeyecekleri sorulmaktadır. Söz konusu gruplar ya toplum tarafindan marjinal olarak görülen gruplar ya da dinsel ve kültürel açıdan kendine yabancı olan gruplardır. Türkiyeli insanların bu gruplar karşısındaki sosyal mesafe tutumları incelendiğinde, özellikle uyuşturucu ve alkol bağımlıları, eşcinseller ve dost hayatı yaşayanlar ve AIDS hastaları ezici bir çoğunluk tarafından komşu olarak kabul edilmemektedir. Başka dil, din ve irktan olanlarla göçmenlere karşı ise daha düşük düzeylerde (yüzde 30-40 arasında) bir kesim çekince ortaya koymaktadır. Bu veriler, teh- 
dit algısının yüksek olarak algılandığı kesimlere karşı mesafeli bir duruşun olduğunu göstermektedir.

\section{Sosyal Mesafenin Sıfır Noktası: Tokalaşma/Eı Sıkışma}

Tanışma veya tanıştırılma kadar günübirlik karşılaşmalarda bazı kültürler, yakın temaslara müsaade etmediği gibi bazı toplumlarda da sınırlı oranda fiziksel temas normal karşılanmaktadır. Sözgelimi Jopanya'da günübirlik karşılaşmalarda bedensel olarak hafifçe eğilmek yeterli bir selamlaşma olarak görülürken, pek çok toplumda sözlü selamlaşmaya tokalaşma eşlik etmektedir. Tokalaşma, sosyal mesafenin sıfırlandığı bir noktadır. Çünkü iki kişi birbirinin elini sıkarak fiziksel bir temas kurmaktadır. Hatta bunu yaparken daha samimi olan kişiler, sarılma ve öpme gibi davranışlar bile sergilemektedir. Bu ileri giden bir samimiyet ve güvenin göstergesi olarak tanımlanabilir.

Avrupa, Amerika ve Ortadoğu ülkelerinde tokalaşma çok yaygın olup tarihi de çok eskilere dayanmaktadır. Bu ritüelin kökeni tam olarak bilinmemektedir. Bazıları Roma askerleri arasında yaygın olan Mithras ritüelinin bunun kökenini oluşturduğunu iddia etmektedir. Bu kültürlerde, uzatılan eli geri çevirmek bir incitme ve nezaketsizlik olarak görülür. Akdeniz ve Doğu Avrupa ülkelerinde el sıkışmasının ötesinde insanlar (erkek ve kadınlar bazen ayrı bazen de cinsiyet ayırt etmeden) birbirileriyle öpüşürler. Bunun İncil metinlerinde de örneği bulunmaktadır (Kitâb-ı Mukaddes, 1997). Bazı ülkelerde tokalaşma hukuka da girmiştir. Sözgelimi Belçika'da resmi yetkililer, nikâh aşamasında eşlerle el sıkıştan sonra nikâh kıymaktadırlar.

Tokalaşma yaygın olmakla birlikte her kültürde tokalaşma adabı aynı değildir. İki farklı örnek üzerinde durmak, tokalaşma adabının nasıl detaylı bir işlemler serisi olduğunu ve nasıl anlamlandırıldığını ortaya koyacaktır.

Müslüman dünyada selamlaşma, tokalaşma ve sarılma gibi işlemler İslamiyet'in ilk yıllarına kadar gitmekte ve Hz. Muhammed'in sünnetine dayandırılmaktadır. Tokalaşma "musafaha" olarak ifade edilir ve bu sözcük, "bir şeyin yan tarafı" anlamına gelen safh kökünden türetilmiştir. Tokalaşmada eller karşılıklı avuç içleri birleşecek şeklinde tutulduğundan buna musâfaha denilmiştir. İslâm'da Müslüman kardeşliğini güçlendirmek için selâmlaşma, musâfaha ve güleryüzlülük teşvik edilmiştir. Selâmlaşmanın bir parçası sayılan tokalaşma, Hz. Peygamber'in sünnetinde yer alan âdâb-ı muâşeret kaidelerindendir (Bozkurt, 2012: 217).

Müslüman kültüründe selamlaşma ve bunu tamamlayan el sıkışma ve hatta sarılma gibi davranışlar, insanlar arasında dostluk, barış ve dayanışmayı güçlendirmek amacıyla yapılır. Bu eylemlerle insanlar birbirlerine "ben senin dostunum" veya "benden sana zarar gelmez" şeklinde mesajlar verirler.

İslam kültür tarihinde tokalaşmanın çok eskiden beri var olduğu belirtilir ve ilk tokalaşma âdeti Hz. İbrâhim'e dayandırılır. Alışveriş esnasındaki tokalaş- 
ma veya elleri hızlıca birbirine vurma âdeti "safka" kelimesiyle ifade edilir (Bozkurt, 2012: s.217). Bu veriler tokalaşmanın tüccarlar tarafından geliştirilen bir pazar âdeti olduğunu ima etmektedir. Pazarda tüccar ve müşterilerin alışveriş yaparken pazarlığa girişmeleri ve fiyatı düşürmek için samimiyeti ifade eden el sıkışmaları, muhtemelen daha sonra tüm toplumsal ilişkileri yumuşatmak gayesiyle yaygınlaştırılmıştır.

Hz. Muhammed'in selamı yaygınlaştırmayı emreden buyrukları olduğu gibi, çeşitli biatlarda da insanlarla el sıkıştığı tarih, siyer ve hadis kaynaklarında yer almaktadır. Âlimler gündelik hayatta uyulması gereken âdâb-ı muâşeret (görgü) kuralları çerçevesinde konuşma, selâmlaşma, sarılma, el veya alından öpme, tokalaşma, karşılama, ayağa kalkma, vedalaşma gibi iletişim biçimlerini bir bütün halinde inceleyerek sünnete uygun âdâbı belirlemeye çalışmışlardır.

Fakih ve bilginler, arada evlilik yasağı bulunup bulunmaması ve yaş gibi kriterlerden hareketle insanları dört grupta ele almışlar ve tokalaşma kurallarını buna göre ortaya koymuşlardır (Bozkurt, 2012: 218-219).

1) Kişinin evlenmesi ebediyen haram olan akrabalarından biriyle tokalaşmasında sakınca bulunmadığı ifade edilmiștir. Bunlar nesep, süt akrabalı̆̆ı veya sıhriyet yoluyla kurulan akrabalıklardır. Ana-baba, dede-nine, kardeşler, yeğenler, hala ve teyze gibi nesep bağıyla, sütanne, sütkardeş gibi süt akrabalı̆̆ı yoluyla ve kayınvâlide, gelin, babanın eşi, eşin kızı gibi sıhriyet bağıyla akraba olunanlarla musâfahada bir sakınca görülmemiştir.

2) Aralarında Hanefîler ve Hanbelîler'in de yer aldığı fakihlere göre mahrem olmasa da yaşlılarla musâfahada bir sakınca yoktur.

3) Yine herhangi bir akrabalık bağı bulunmasa da küçüklerle tokalaşma (Mâlikîler dışındaki) mezheplere göre câiz görülmüştür.

4) Mahrem olanlar dışında karşı cinsten genç ve orta yaşlılarla tokalaşmaya, kadim dönemde fakihler cevaz vermemiştir; günümüzde ise iki farklı görüş bulunmaktadır. Cevaz vermeyenler, Hz. Peygamber'in biat alırken kadınlarla tokalaşmayıp sözle yetindiğine dair rivayetleri delil getirirler. Cevaz verenler ise bunun zorunlu olmadığını ileri sürmektedirler.

Bu kurallar, Müslüman toplumda tokalaşmanın genel ve her zaman bağlayıcı olmadığını, bazı sınırlamaları ve ilkeleri bulunduğunu göstermektedir. Tarihsel süreç içinde de farklı Müslüman toplumlar, bu kuralları kendi yapılarına adapte etmiş ve daha esnek bir tokalaşma kültürü oluşturmuşlardır. Bu bakımdan Türklerle Araplar arasında farklılıklar olduğu görülmektedir. Önemli bir farklılık, cinsiyet farkını dikkate alıp almama kuralıdır. Bu konu bir ülke içinde bile toplumsal kesimlere ve gruplara göre değişkenlik arz eden bir mesele haline gelmiştir.

Müslüman dünyada olduğu kadar Batı kültüründe de selamlaşma ve tokalaşma çok eskilere dayanan bir alışkanlık ya da örf olarak karşımıza çıkmaktadır. 
Bu alışkanlığı Roma'ya ve hatta daha eski dönemlere kadar götürenler bulunmaktadır. Tam kökeni tespit edilmemekle birlikte bilinmesi gereken şey şudur: Selamlaşma ve tokalaşma, modern zamanlarda icat edilmiş yeni bir şey olmayıp, geleneksel toplumlarda da rastlanan bir iletişim biçimidir. Bilakis modern zamanlarda, aşırıya giden bireyselleşme ve sekülerleşme gibi etkenler dolayısıyla toplumsal ilişkiler sarsılmış ve bu tür samimiyet ifade eden eylemlerden bir kaçınma hali ortaya çıkmıştır.

Batı dünyasından birkaç örnek vermek gerekirse, Hollanda ve Belçika'da, özellikle toplantılarda, el sıkışmalar daha sık yapılmaktadır. İsviçre'de önce kadınların elinin sıkılması beklenir. Avusturyalılar toplantılarda sık sık çocuklarla birlikte olmak üzere el sıkışırlar. Amerika Birleşik Devletleri'nde geleneksel bir el sıkışma, sağ el ile, iyi bir duruş ve göz teması ile gerçekleştirilir. Sağlam bir el sıkışmasının tercih edildiği Norveç'te, insanlar anlaşmalarda, özel ve iş ilişkilerinde çoğunlukla el sıkışırlar (Wikipedia, 2020b).

Bununla birlikte ülkeden ülkeye nezaketen dikkat edilmesi gereken çok ince ayrıntılar gözlemlenmektedir. Sözgelimi Hollandalı iletişim bilimci Hans Kaldenbach, kendi ülkesinde geçerli olan kuralları 10 noktada özetlemektedir (Kaldenbach, 2016).

1) Tokalaşmaya başlarken neredeyse uzanmış bir kol ile diğer kişiye doğru yürümelisiniz.

2) Yaklaşırken dirseğinizi bükün ki "doğru” mesafeyi kontrol edebilesiniz.

3) Önce diğer kişiye bakıyorsunuz, sonra kısaca onun eline baklyorsunuz ve ancak bundan sonra tekrar yüzüne bakabilirsiniz.

4) Sağ elinizle tokalaşınız. Sağ kolunuz meşgul ise özür dileyiniz.

5) Elinizi dikey olarak tutun, aksi takdirde sizin baskın veya itaatkâr bir karakter olduğunuzu düşünürler.

6) Ardından başparmağınızın içyüzüyle karşı tarafın avuç içini sıkıca tutunuz.

7) Şimdi elinizi sıkıștırmalısınız. Hollandalılar bunu baskın, zorlayıcı veya saldırgan bulmazlar. Eğer bunu yapmazsanız sizi zayıf bulacaklardır.

8) Karşı tarafin ellerini tuttuktan sonra bir kez dikey olarak sallayın, ardından iki kez daha kendiliğinden aşağı-yukarı sallanma olacaktır.

9) Bu esnada gülümsemelisiniz ve/veya kafanızı hafifçe eğip kaldırmalısınız.

10) Son olarak bașparmağınızı diğer kişinin yumuşak etine sıkıca bastırıp noktayı koymalısınız. Bu işaretten sonra diğer kişi sizin ne demek istediğinizi hisseder!

Bu kurallar, eșitlikçi ve kendine güveni olan bir insan tipinin varlığını ima etmektedir. Üstelik bu kurallar uygulanırken, karşınızdaki kişinin yerli-yabancı veya kadın-erkek olması hiç önemli değildir. İlk tanışmada tokalaşma olmaz- 
sa, bir Hollandalı kendini sizinle tanışmış saymaz. Yine zaman zaman karşılaşmalarda, tokalaşmazsanız bir şeyin eksik kaldığını düşünür.

\section{Sosyal Mesafenin En Uç Noktası: Gettolaşma ve Karantina}

Sosyal mesafenin sıfır noktası tokalaşma ise, en uç noktası ise toplumsal yalıtlanmadır. Toplumsal yalıtlanmanın ise eskinden beri bilinen iki biçimi bulunmaktadır: Gettolaşma ve karantina. Getto kelimesi İtalyanca bir kelime olup bir grubun belirli bir mekânda yoğunlaşmasını ve ikametini anlatan bir kelimedir. Venediklilerin dilinde geta kelimesinden türetilmiştir ve demir dökümhaneden çıkan kalıntıları ifade etmektedir. Bunun sebebi İtalya'da Yahudilerin yaşamak zorunda kaldığı yerde bir demir dökümhanesinin bulunuyor olmasıdır (Wikipedia, 2020a). Tarihte Yunan şehir-devletlerinde yabancılar için ayrı bir mahalle tahsis edildiği ve ilk getto uygulamasının burada başladığı bilinmektedir. Ortaçağda, 1179 yılında Üçüncü Lateran Konsili'nin aldığı bir kararla, Yahudiler yerleşik toplumdan ayrı bir yerde ikamete mecbur edilmiştir. Takip eden yüzyıllarda Portekiz, İspanya, Almanya, İtalya ve Polonya gibi çoğu Avrupa ülkelerinde gettolar ortaya çımıştır.

Gettolaşmanın amacı, sakıncalı ve tehditkâr görülen gruplarla yerleşik toplum arasına bir mesafe koymaktır. Bu mesafenin ikili bir işlevi olduğu söylenebilir: Bir yandan tehdit olarak algılanan gruptan toplum korunduğu gibi, diğer yandan o grubun kendisini topluma ait bir grup olarak hissetmesi de engellenir. Sosyal mesafeden dolayı söz konusu grup hakkında önyargılar ve kalıpyargılar oluşur, bunlar bazen yüzyıllar boyunca topluma yerleşir ve atılması imkânsız hale gelir.

Toplumun geneli açısından bakıldığında, her gettolaşma ve segregasyon toplumda farklı yapıların ve oluşumların ortaya çıkması anlamına gelmektedir. Eğer bir toplumda giderek nüfus olarak da büyüyen bir grubun toplumsal yalıtlanması söz konusu ise, burada toplumun ikiye ayrılması ya da ikili bir toplumun oluşması kaçınılmazdır. Bu tür toplumları, toplumbilimciler ve siyasetçiler "paralel toplumlar" olarak da adlandırmaktadırlar. Paralel toplumlarda en büyük korku, sosyo-ekonomik, etnik ve hatta kültürel bakımdan giderek derinleşen çelişkilerin gerilimlere ve çatışmalara dönüşme ihtimalidir (Cana$\tan , 2011: 14$ ).

Gettonun zıddına karantina tıbbi bir terim olup, 14. yüzyılda veba salgını sırasında İtalya'da ortaya çıkmıştır. Veba salgını sırasında limanlara gelen gemiler 40 gün bekletilmiş ve bu sürede mürettebat ve yolcuların gemiyi terk etmesi yasaklanmıştır. Karantina kelimesi İtalyanca'da 40 sayısının karşılığı olan "quaranta" kelimesinden türemiştir. Karantina, bulaşıcı bir hastalığa maruz kalan şüpheli durumdaki insan ve hayvanları, hastalığın en uzun kuluçka devresine eşit bir süre kimseyle temas ettirmemek suretiyle alınan tedbirsel faaliyetlerin tümüdür, sağlık amaçlı bir yalıtımdır. 
Getto ile karantina arasında temel bir fark vardır: İlkinde insanları dışlama eğilimi varken, ikincisinde insanları koruma eğilimi söz konusudur. Ama ortak bir paydada buluştukları da söylenebilir: Her ikisinde de yalıtım konusu olan kişiler "sakıncalı" ilan edilmiştir. Bu sakınca ilkinde kurgusal, ikincisinde ise gerçekçidir.

$\mathrm{Bu}$ tarihsel bilgiler bir tarafa, getto ve karantina yöntemleri günümüzde de halen geçerli olan uygulamalardır. Geçmişte olduğu gibi yabancıları ve azınlıkları zorla bir mahalle veya mekânda tutmak söz konusu olmasa da, Avrupa ve Amerika gibi ülkelerde altsınıflar, göçmenler ve azınlıklar halen belirli mahallelerde yoğunlaşmış olarak yaşamaktadırlar. Bunlarla yerleşik toplum arasında ciddi bir sosyal mesafe olup, bu mesafe aynı zamanda söz konusu grupların toplumla bütünleşmesinin önünde bir engel olarak görülmektedir. Günümüzdeki gettolaşma daha çok sosyo-ekonomik sebeplere dayanmaktadır. Düşük gelirli gruplar eski ve ucuz evlerin bulunduğu mahallelerde yaşamak zorunda kalmakta ve böylece şehir, seçici bir konut piyasasıyla yapılandırılmaktadır. Bunu önlemenin yollarından biri, dağıtım politikası olup düşük gelirliler kendileri için yapılan başka semtlerdeki konutlara yerleştirilmektedir. Ya da kirası yüksek olsa bile, kira yardımları ve destekler verilerek düşük gelirli grupların başka mahallelere taşınması teşvik edilmektedir.

Karantina, salgınlar söz konusu olduğunda uygulanan bir yöntemdir. 2019 sonu 2020 başı itibariyle maruz kaldığımız salgında yurtdışından gelen insanlara 14 günlük bir karantina uygulanmaktadır. Bunun dışında 65 yaş üstü yaşlılar ile 20 yaş ve altındaki çocuklar ve gençlerin sokağa çıkması yasaklanarak evlerinde karantina altına alınmaları sağlanmıștır. Bunun dışında ivedi işleri olmadıkça, insanların dışarda ve kamusal alanda dolaşmamaları konusunda uyarılar yapılarak "gönüllü" bir karantina uygulamaları talep edilmiş ve bu büyük oranda uygulanmıștır. Ayrıca 30 büyükșehir ve Zonguldak ilinde zaman zaman sokağa çıkma yasağı uygulanarak zorunlu karantina tedbirleri alınmıştır.

$\mathrm{Bu}$ tedbirler toplu olarak düşünüldüğünde bu küresel dünyada uygulanan ilk zorunlu ve gönüllü karantina olup milyonlarca insan birbirinden yalıtlanmıştır. Çünkü korona virüs ya da "COVID-19" olarak adlandırılan bu salgın, küresel bir salgın olup tüm dünyayı ve insanlığı tehdit etmektedir. Virüsün yayılma eğilimi ve yayılma merkezleri doğrudan doğruya küreselleşme düzeyiyle alakalıdır. Nasıl küresel çağda mal, sermaye, işgücü ve bilgi serbestçe dolaşım halindeyse, bir bölge ya da ülkede ortaya çıkan virüs salgını da hızla küreselleşme mekanizmaları yoluyla yayılmaktadır. Salgın, küresel olduğu gibi sosyal, ekonomik, politik ve diğer etkileri de küresel nitelikte olacaktır.

\section{Krizlerin Sosyal Mesafeye Etkisi}

Krizler, günlük rutinlerin bozulmasına neden olduklarından her şeyi sil baştan yeniden düşünmek zorunda kalırız. Normal günlerde kullandığımız kri- 
terler değişir, hatta çok köklü alışkanlarımızı gözden geçirmemiz gerekebilir. 2020 yılında koronavirüs salgını çıktığı ve dünyaya yayıldığı ilk haftalardan bu yana, hayatımızın ezberleri bozulmuş durumdadır. En önemli değişim, günlük hayat trafiğinde gerçekleşmiştir. İnsanlar önce evlere çekildi, sonra sokaklar ve yollar boşaldı. Uzayacağı anlaşılınca insanlar işlerini evlerine taşıdılar. Milyonlarca insan işyerlerini terkettiler ve evde çalışma düzenine geçtiler. Ardından şehirlerarası ve ülkelerarası ulaşım kesildi. Acil ve ihtiyaç olmadıkça, kimse yerinden kıpırdamadan yaşamak zorunda kalmıştır. Önce 65 yaş ve üzerinin sokağa çıkmasının yasaklanması, sonra bu yasağın kapsamına 20 yaş altının eklenmesi, çok önemli bir nüfus kesiminin günlerce ve haftalarca içerde kalmasına yol açmıştır.

Korona virüs salgını, ekonomiyi, eğitimi, siyaseti, sağlı̆̆ı, medyayı; kısacası hayatımızın tüm alanlarını ve boyutlarını derinden etkilemektedir. Ekonomide üretimin azalması ve bazı sektörlerin durması hem sektörü hem de ülkeyi büyük zararlara sokmaktadır. Örgün ve kurumsal eğitim, artık fiilen uzaktan eğitime dönüşmüş durumdadır. Siyaset, sağlık ve medya sadece bir konuyla uğraşmaktadır: Salgın bizi nasıl etkiliyor ve neler yapmalıyız? Şimdilerde herkesin aklını bu soru meşgul etmektedir. Şu ana kadar bu sorunun cevabı, "sosyal mesafe" ilkesini her yerde yaşama geçirmek şeklinde olmuştur. Çünkü söz konusu salgın, etkileşim yoluyla yayılmaktadır. Salgın, Çin'in bir bölgesinde (Vuhan) başlamış ve hızla Ortadoğu, Avrupa ve Amerika'ya kadar yayılmıştır. Küresel trafiği kesmek, salgını önlemenin en önemli şartıdır.

Peki, bu yaşadığımız korona virüs salgını başta olmak üzere, krizler sosyal mesafeye nasıl etki etmektedir?

Bugün yaşadığımız krizden sonuçlar çıkarmaya çalışırsak, bu aldatıcı olacaktır. Farklı türden krizleri incelediğimiz zaman, ideal-tipik üçlü bir tipoloji geliştirmek mümkün görünmektedir:

1) Deprem gibi doğal felaketler: Sosyal dayanıșmayı artırırken sosyal mesafe de azalmaktadır.

2) Bulaşıcı hastalıklar: Hem sosyal dayanıșmayı hem de sosyal mesafeyi artırmaktadir.

3) Terör gibi şiddet eylemleri: Eylemcilere karşı düşmanlığı (dolayısıla sosyal mesafeyi) artırır, ama mağdurlarla dayanışmayı attırır (dolayısıyla sosyal mesafeyi de azaltır).

Sosyal bilimciler açısından "sosyal dayanışma" ve "sosyal bütünleşme", toplumsal yapının sağlamlığını ifade eden kavramlardır. Özellikle modern toplumda aşırı bireycilleşme, sosyal kontrolün azalması, anominin artması vb. gelişmeler sosyal yapıyı ve sosyal dayanışma ağlarını çözmektedir. Modern toplum, sosyolog Zijderveld'in ifade ettiği üzere "soyutlaşmak"tadır. Modern toplum, ona göre "soyut toplum"dur. Soyut toplumda ilişkiler ağ ç̧eşitlenmekte, kırılgan hale gelmekte, çok esnek ve mesafeli bir şekle kavuşmaktadır. Ya- 
pısal anlamda bunlar olurken, kültürel anlamda da değerler genel, belirsiz ve serbest yüzer-gezer bir hale gelmektedir (Zijderveld, 2014).

Bu saydığımız gelişmeler modern toplumda meydana gelirken ve herkes bu gelişmeleri meşrulaştırmaya çalışırken, birdenbire ortaya çlkan krizler hayatımızda beklenmedik etkiler ve sonuçlar doğurmaktadır. Çoğu felaketler genellikle sosyal dayanışmayı artırmaktadır. İnsanlar krizle mücadele etmek için birbirine kenetlenmekte ve bu kenetlenmenin yarattığı sinerjiyle yaraları sarmaya çalışmaktadırlar. Kur'an'da haber verilen bir şey gerçekleşmektedir: "Sizin şer gördüğünüz bir şey hayır; sizin hayır gördüğünüz bir şey de şer olabilir" (Bakara Suresi, 2:126). Korona virüs salgını șüphesiz ki bir șerdir! Binlerce insan ölüyor ve krizin çok yönlü olumsuz etkileri var. Ama öte taraftan, insanlar krizi önlemek için kampanyalara katılıyor, kendi evine ve ailesine sahip çıkıyor ve hatta ülkeler başka ülkelere çeşitli türden destek ve yardımlar veriyorlar. Hiç kimsenin normal zamanlarda başaramayacağı bir dayanışma sergileniyor.

Yine paradoksal olan bir başka durum var: Salgını önlemek için sosyal mesafeyi korumak ve ısrarla uygulamak zorundayız. Başka bir deyişle normal zamanlarda yaptığımız eylemleri ve davranışları yapmaktan kaçınıyoruz ve kaçınmalıyız da. Hem kenetlenme ve sosyal dayanışma hem de sosyal mesafe kurallarını uygulamak, aynı anda başarılmalıdır.

Mecelle'de yer alan bir kural, bu paradoksu şöyle açıklar: "Zaruretler, yasak olan şeyleri serbest kılar" (Akgündüz, 2018). Bu ilke, bazen "Aciliyet yasayı iptal eder" şeklinde de ifade edilir. Eğer ortada acil ve zorunlu bir durum varsa, normal zamanlarda geçerli olan kurallar geçersiz hale gelirler. Bulaşma tehlikesi, tokalaşma ve sarılma gibi adap kurallarını ortadan kaldırmıştır. Hatta ibadet mekânlarında toplu olarak namaz kılmak ve dua etmek iptal edilmiștir. Bununla namaz ve dua mutlak olarak iptal edilmiş değildir. Dini ibadetlerin ev ortamında sürdürülmesi pekâlâ mümkündür. Her şeyin eve sığdırıldığı böyle bir dönemde ibadetler de eve sığdırılabilir. Ancak bu durumlar arızidir, geçicidir.

Geleceği öngörmek çok zor, ancak bu salgının süresine bağlı olarak bazı şeyler söylenebilir. Eğer salgın kısa sürede engellenirse, aradan bir süre geçtikten sonra, bu kriz günlerini hızla unutacağız ve hiçbir şey olmamış gibi eski günlere döneceğiz. Kriz öncesi yaşadığımız hayatın rutinleri tamamen devreye girecektir. Bugünlerden hatırladığımız birkaç enstantaneyi zaman zaman hatırlayacağız ve belki çocuklarımıza ve torunlarımıza geçmişten anılar olarak anlatacă̆ız.

Eğer kriz uzun sürerse -ki bu hepimizi korkutuyor- hayatımızda birçok şeyi değiştirmek zorunda kalacağımız gibi, "kriz öncesi ve sonrası" diye cümleler kurmaya başlayacağız. Özgürlüğümüz kadar güvenliğimizi de düşüneceğiz. Çok tüketmeyi değil, azla yetinmeyi başaracağız. Sağlık çalışanlarına daha fazla saygı göstereceğiz. Çocuklarımız için sağlıkçı ve güvenlikçi olmayı salık ve- 
receğiz. Bu iki meslek yakın gelecekte yükselişe geçecektir. Temizlik kurallarını önemle ve özenle yerine getirmeye çalışacağız. Daha çok hareket ve spor yapacağız. Kolayca kirlettiğimiz parkları ve toplu yaşam alanlarının kıymetini daha iyi bileceğiz ve daha temiz kullanacağız. Belki kriz günlerinin otoriter havasını içselleştirmiş ve başıboş serbestliğin özgürlük olmadığını öğreneceğiz. Hayatımıza ve ailemize verdiğimiz önem bir kat daha artacaktır. Sosyal mesafeyle ilgili olarak eski samimiyetten ve bedensel temaslardan kaçınacağız. Bu, bugün modern toplumlarda uygulanan "Uygar kayıtsızlık" (Goffman, 1971) stratejisinden daha başka ve çekinceli bir sosyal ilişki biçimi olacaktır.

Sokağa çıkmaya, normal hayata dönmeye özlem duyuyoruz fakat salgın sona erse bile hayatımızın ciddi bir şekilde değiştiği konusunda da hem fikiriz. Ipsos'un yaptığı "Koronavirüs ve Toplum Araștırması"na göre Türkiye'de kamuoyunun \%70'i bir süre sonra sona erse bile, koronavirüs salgınının hayatımızı ciddi bir şekilde değiştireceğini düşünüyor (Ipsos, 2020b).

Etkisi uzun süren felaketlerin toplum psikolojisini değiştirdiği gibi buna bağlı olarak dini tutum ve kanaatlerde de değişmelere yıl açacağı beklenebilir. Krizler genellikle insanların dindarlaşmasına veya en azından varoluşsal sorular sormasına sebep olurlar. Dünyada oldukça sağlam ve istikrarlı bir konumu olan insanların bu konumu kaybetmesiyle dünyanın pek de güvenilecek bir liman olmadığı ortaya çıkmaktadır. Bu durumda insanlar daha güvenilir bir sığınak arayışına girmektedirler. Bu sığınak çoğunlukla Tanrı ve dindir. Çünkü Tanrı insanları mutlak gücüyle koruyabileceği gibi, belirli bir dinin kendi mensupları arasında sergilediği dayanışma ve kurduğu samimi ilişkiler, adeta Tanrı'nın bir rahmeti ve yardımı olarak algılanmaktadır.

Küresel salgının etkileri çok yönlü olacaktır. Sağlıkçılar ve tıpçılar toplum sağlı̆̆ına etkilerini, sosyologlar ve psikologlar toplumsal ilişkilere ve ruhsal yapılara etkilerini araştırırken, elbette iktisatçılar ve siyaset bilimciler ekonomi ve siyasete etkilerini tartışmaktadırlar. Ekonomik hayatta toptan bir durgunluktan bahsetmek aşırı bir kötümserlik olacaktır. Kriz, ekonomide bazı sektörleri geriletirken, bazı sektörleri de geliştirecektir. Sözgelimi kargo ve iletişim hizmeti veren firmalar ve kurumlar yanında sağlık hizmeti ve ürünleri pazarlayan kurumlar da bu dönemde en kazançlı çıkacak sektörlerin başında gelmektedir. Toplumun yaşam tarzı değişince, üretim ve tüketim biçimleri de değişmektedir. Krizin başladığı günden bu yana hanelerin satın aldığı hızlı tüketim ürünleri harcamalarında önemli değişiklikler görülmektedir: İçecek ürünlerinde, bağışıklık sistemini güçlendirici olduğuna yönelik haberlerin de etkisi muhtemelinde Turşu tüketiminde, diş macunu ve diş fırçalarının satımında artışlar dikkat çekmektedir. Ayrıca evde yemek yapma ve yemek yeme sayısının artması ile hazır yemekler ve soslarda da artışlar gözlemlenmiștir (Ipsos, 2020a).

Gerek Avrupa gerekse Türkiye'de yapılan tartışmalarda siyasal rejimlerde bir otoriterleşme eğiliminden bahsedilmektedir. Çünkü Hollandalı bir felsefecinin belirttiği gibi "Korona korkusundan dolayı, normal zamanlarda hiçbir şekilde vermeyeceğimiz şekilde hükümetlere yetkiler veriyoruz." (Huijer, 2020). $\mathrm{Bu}$ yetkilerin kronikleşmesi ve rutinleşmesi kesinlikle siyasette bir otoriter- 
leşme anlamına gelecektir. Korona salgını gerek iktidarları gerekse kurumları bir teste tabi tutmaktadır. Bu krizle mücadele etmede yetersiz kalan hükümetler yeni bir seçimde çekip gidecekler ve yerlerine başkaları gelecektir. Amerika'da Michigan eyaletinde eyalet valisine karşı yapılan aşırı sağcı grupların silahlı gösterisinde görüldüğü üzere, bu salgının sokak hareketlerini de hızlandıracağı beklenmelidir. Bu gösteri de ilginç olan nokta, ilkesel olarak otoriterlik yanlısı olan bir grubun "evde kal" tedbirleri çerçevesinde alınan kararlara karşı çıkmasıdır. Yasakların uzaması ve tedbirlerin sertleşmesi durumunda hükümet güçleriyle eylemci grupların sık sık karşı karşıya gelmesi hiç beklenmedik bir gelişme olarak görülmemelidir.

\section{Sonuçlar}

Krizlerin sosyal mesafeye etkilerinin tartıșıldığı bu makalede ulaştığımız sonuçları birkaç noktada özetlemek mümkündür. İlk olarak krizler normal günlerde geçerli olan sosyal mesafeye dair kuralların ve standartların kırıldığı ve her şeyinden yeniden düşünüldüğü bir süreci harekete geçirmektedirler. $\mathrm{Bu}$ süreç, katlanılması ve baş edilmesi zorlu bir süreçtir. Çünkü insanoğlu alışkanlıklarını kolayına terk edememektedir.

İkinci olarak krizlerin sosyal mesafeye etkisi, tek yönlü ve tek biçimli bir etki olarak değerlendirilmemelidir. Bazı krizler, depremler örneğinde görüldüğü gibi sosyal mesafe ve dayanışmayı aynı anda artırırken, bazıları da sosyal mesafeyi azaltırken sosyal dayanıșmayı artırmaktadır. Özellikle bugünlerde yaşanmakta olan coronavirüs salgını bu ikinci kategoride değerlendirilmelidir. Terör olaylarında görüldüğü gibi başka krizlerde ise sosyal mesafe, eylemcilere yönelik olarak düşünüldüğünde uç noktada dışlayıcı iken, mağdurlara karşı sosyal mesafe olmadığı gibi dayanışma da oldukça yüksektir.

Son olarak krizler dönemi, arızi olarak görülmesi ve sosyal normların geçici olarak iptal edildiği bir zaman kesiti olarak düşünülmelidir. Bu dönemlere özgü yasa, Mecelle'de ifade edildiği üzere "Zaruretler, yasak olan şeyleri serbest kılar" yasasıdır. İbadetlerin mabetlerde yapılmasının iptalinden, tokalaşma ve sarılma gibi günlük hayat ritüellerinin uygulanmasından kaçınılması kadar alınan tüm tedbirler, krizlerle baş etmek ve savuşturmak içindir. $\mathrm{Bu}$ gayeye matuf oldukları sürece de meşru ve işlevsel tedbirlerdir.

\section{Kaynakça}

Akgündüz, A. (2018). Karşılaştırmalı Mecelle-i Ahkam-ı Adliye (Mecelle Ta'dilleri ve Gerekçeleriyle Birlikte), İstanbul: OSAV Yayınları.

Bogardus, E. S. (1933). A Social Distance Scale, Sociology \& Social Research, 17, 265271.

Bozkurt, N. (2012). Tokalaşma. TDV İslâm Ansiklopedisi, 41, 217-219.

Canatan, K. (2011). Hollanda'da Etnik İlişsiler, Gettolaşma ve Paralel Toplum Tartışmaları. Sosyo-Ekonomi, Göç Özel Sayısı, (15), 7-28.

Goffman, E. (1971). Relations in Public: Microstudies of the Public Order. London: Allen Lane. 
Huijer, M. (2020). Heiligt het doel de middelen? Filosoof Marli Huijer: 'Ik weet eigenlijk niet wat het doel is. De Volkskrant: https://www.volkskrant.nl/nieuws-achtergrond/heiligt-het-doel-de-middelen-filosoof-marli-huijer-ik-weet-eigenlijk-niet-wat-het-doel-is b70b08df/ [09.06.2020].

Huijnk, W. J. J., \& Dagevos, J. F. L. M. M. (2012). Dichter bij elkaar?: de sociaal-culturele positie van niet-westerse migranten in Nederland. Sociaal en Cultureel Planbureau.

Ipsos. (2020a). Hane İçi Hızlı Tüketim Ürünleri Satın Alımında İçecek Ürünleri Dikkat Çekti: https://www.ipsos.com/tr-tr/hane-ici-hizli-tuketim-urunleri-satin-aliminda-icecek-urunleri-dikkat-cekti [17.04.2020].

Ipsos. (2020b). Koronavirüs Salgını ve Toplum Araştırması 4. Dönem'den Öne Çıkanlar: https://www.ipsos.com/tr-tr/koronavirus-salgini-ve-toplum-arastirmasi-4-donemden-one-cikanlar [17.04.2020].

Kitâb-ı Mukaddes. (1997). Selaniklilere Birinci Mektup, 5:26; Petrusun Birinci Mektutı bu, 5:14. İstanbul: Kitabı Mukaddes Şirketi.

Kaldenbach, H. (2016). Doe maar gewoon. Amsterdam: Prometheus.

Planbureau, S. C., \& voor het Regeringsbeleid, W. R. (2014). Gescheiden werelden? Een verkenning van sociaal-culturele tegenstellingen in Nederland. Den Haag: https://www.wrr.nl/binaries/wrr/documenten/publicaties/2014/10/30/gescheiden-werelden-een-verkenning-van-sociaal-culturele-tegenstellingen-in-nederland/Gescheiden-werelden-verkenning-sociaal-culturele-tegenstellingen-Nederland.pdf [05.05.2020].

Kuipers, G. \& Van den Haak, M., (2014). De cultuurkloof? Cultuurverschillen en sociale afstand in Nederland, In: Gescheiden werelden? Een verkenning van sociaal-culturele tegenstellingen in Nederland. Den Haag.

Taşkın, E. O., Şen, F. S., Özmen, E., \& Aydemir, Ö. (2006). Kırsal kesimde depresyonlu hastalara yönelik tutumlar: sosyal mesafe ve etkileyen etmenler. Türkiye'de Psikiyatri, 8(1), 11-17.

Wikipedia. (2020a). Getto: https://nl.wikipedia.org/wiki/Getto [17.04.2020].

Wikipedia. (2020b). Handshake: https://en.wikipedia.org/wiki/Handshake [16.04.2020].

World Values Survey. (2020). http://www.worldvaluessurvey.org/wvs.jsp [15.04.2020].

Zijderveld, A. C. (2014). Kültür Sosyolojisi. İstanbul: Açılım Kitap. 